\title{
Organisations not individual people are to blame, says Francis
}

Mid Staffordshire NHS Trust's finance director was John Newsham, not David Newsham, as we incorrectly published in this News story (BMJ 2013;346:f849, doi:10.1136/bmj.f849).
Cite this as: BMJ 2013;346:f861

๑ BMJ Publishing Group Ltd 2013 